\title{
FREKVENCIAVÁLTÓS HAJTÁS KÜLÖNBÖZŐ FELHASZNÁLÁSI LEHETŐSÉGEINEK MODELLEZÉSE
}

\section{MODELLING DIFFERENT USING POSSIBILITIES OF FREQUENCY INVERTER DRIVE}

\author{
Fülöp Márton Károly \\ Debreceni Egyetem, Müszaki Kar, Mechatronikai Tanszék, Debrecen, Magyarország, \\ fulop.marton96@gmail.com
}

\begin{abstract}
In many fields of industry frequency inverter drive is used to make rotation, where it requires modifying the speed of the engine, because of given technological or productional process. In my article I show a model built by us, through which I represent the frequency inverter drive's principal from different fields of the industry by using industrial automation devices. With the help of my model you can become familiarized with 4 use methods created by me, that I can control through a complex, but easy-to-use and user friendly HMI.
\end{abstract}

Keywords: frequency inverter, asynchronous motor, PLC, HMI, conveyor.

\section{Összefoglalás}

Az iparban számos területen használnak frekvenciaváltós hajtást forgómozgás megvalósítására, ahol a motor fordulatszáma változtatást követel adott technológiai vagy gyártási folyamat miatt. Cikkemben egy általam megépített modellt mutatok be, mellyel ipari automatizálási eszközökkel szemléltetem a frekvenciaváltós hajtás felhasználási elveit az ipar különböző területeiről. A modellem segítségével megismerhető az általam megalkotott négy módszer, melyet egy összetett, de átlátható és felhasználóbarát kezelőfelületen keresztül tudok irányítani.

Kulcsszavak: frekvenciaváltó, aszinkron motor, PLC, HMI, szállítószalag.

\section{Bevezető}

Az iparban a legelterjedtebb villamos forgógép a háromfázisú aszinkron motor. Ezeket a villamos motorokat több technológiai folyamatban a szállítószalagoktól kezdve, a szivattyúkon keresztül a ventilátorokig alkalmazzák. Számos esetben előfordul, hogy a motorokat nem csak az $50-60 \mathrm{~Hz}$ frekvenciájú hálózati feszültéghez tartozó fordulatszámon kell üzemeltetni. Ezekben az esetekben szükséges az aszinkron motor fordulatszám változtatása. [1], [2].

$$
\begin{aligned}
& s=\frac{n_{0}-n}{n_{0}} \Rightarrow n=(1-s) \cdot n_{0} \\
& n_{0}=\frac{f_{1}}{p}
\end{aligned}
$$

$$
n=\frac{f_{1}}{p} \cdot(1-s)
$$

s - csúszás (szlip) [-];

$\mathrm{n}_{0}$ - álló részben a mágneses tér fordulatszáma [1/perc];

n - forgó rész fordulatszáma [1/perc];

$\mathrm{f}_{1}$ - frekvencia [Hz], [1/másodperc];

p - póluspárok száma [-].

A 3. egyenletből kiolvasható, hogy a fordulatszámot három tényező befolyásolja: frekvencia, póluspár szám és a szlip. Ha a három paraméter közül megváltozik bármelyik, akkor megváltozik a motor fordulatszáma is. 


\section{Felhasználási elvek}

Kutatásom során 5 általános felhasználási elvet különböztettem meg a frekvenciváltós hajtás alkalmazásaiban:

- több előre beállított sebesség használata;

-két érték közötti lineáris sebesség változtatás;

- gyorsulási idő optimalizálása;

- fékezési idő optimalizálása;

- sebesség tartás terhelés változtatására.

Ezeket az elveket felhasználva különböző területeken alkalmazzák a frekvenciaváltós hajtást az épületautomatizálástól kezdve az anyagszállításon keresztül egyetemi kutatásokig. [3]

\section{Felhasznált eszközök és kommuniká- ciójuk}

Modellem megvalósításához a Mitsubishi Electric ipari automatizálási eszközeit egy frekvenciaváltót (Mitsubishi DR-E720S-008SC-EC), egy PLC-t (Mitsubishi FX3GE-24MT/DDS), egy HMI-t (Mitsubishi GT1045-QSBD) és szoftvereit (GX Works2, GT Designer3), a Bernstein (Bernstein KCN-T12PS/004-KLP2) szenzorjait, melyeket a Festo is forgalmaz, egy Carpanelli (Carpanelli M63B4) által gyártott három fázisú aszinkron motort (0,18 kW; $230 \mathrm{~V} ; 1,15 \mathrm{~A}$; IP55) valamint egy a tanszéken található szállítószalagot használtam fel.

\subsection{Eszközök közötti kommunikáció}

A rendszeremben az eszközök közötti kommunikációt a 2. ábra szemlélteti. A HMI és a PLC között RS422 kapcsolattal jön létre a kommunikáció. A PLC be és kimenetei a frekvenciaváltó sorkap-

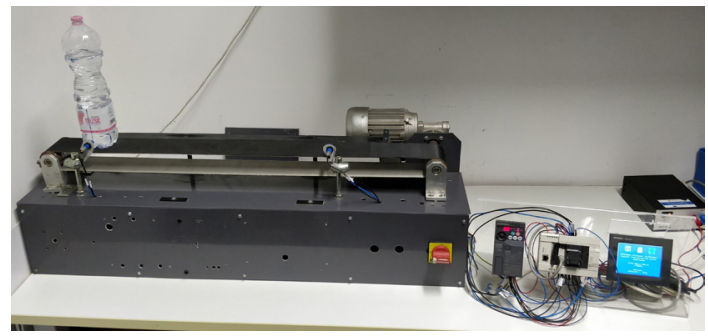

1. ábra. A megépített modell

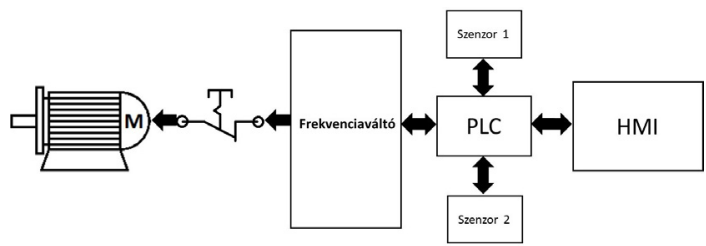

2. ábra. Az eszközök közötti kommunikáció sematikus ábrája csain keresztül küldik, illetve fogadják az adatokat. A frekvenciaváltóba a motor három fázisa a frekvenciaváltó kézikönyvében leírt módon van bekötve, így tudja a kapott vezérlő és szabályozó jelek függvényében megfelelően irányítani azt. Biztonsági okokból a motor és a frekvenciaváltó közé egy vészkapcsolót építettem be, hogy a motort bármikor áramtalanítani tudjam a frekvenciaváltó kikapcsolása nélkül.

\subsection{Frekvenciaváltó paraméterezése}

Ahhoz, hogy a frekvenciaváltó, a motor és a PLC közötti kommunikáció zavartalanul létrejöjjön, a frekvenciaváltót fel kell paraméterezni. A rendszer biztonságos működéséhez elengedhetetlen a maximális és minimális frekvencia, a gyorsítási és fékezési idő, a motor adatai, valamint a felhasznált kapcsok beállításai, melyek paraméterezését manuálisan végeztem el.

$\mathrm{Az}$ analóg kimeneti kapcsok 0-10 V jelszinten keresztül kommunikálnak, viszont az analóg bemeneten a jelszintet ki kell választani, így a paraméterezés során a bementi kapcsokra szintén 0-10 V kommunikációs jelszintet állítottam be. Alapesetben a 4-es analóg bemeneti kapocs inaktív a frekvenciaváltón. Mivel az általam használt frekvenciaváltó a termékcsalád legkisebb tagja mind méretben, mind teljesítményben, ezért a vezérlő kapcsok egyikét át kellett paramétereznem AU signal kapoccsá és aktiválni, így a 4-es kapocs használhatóvá vált.

\section{Megvalósított modell bemutatása}

Az irányító PLC programjaimat a Mitsubishi Electric által fejlesztett GX Works2, míg a HMI kezelőfelület vizualizációját GT Designer3 fejlesztőkörnyezetben készítettem el.

A rendszer indításakor általános ismertetést kapunk a modellről, majd a harmadik oldalon tudjuk kiválasztani az alkalmazni kívánt példát. A rendszer tervezésekor fontos szempont volt, hogy egyszerűen kezelhető legyen, ezért a 4 programot 2 csoportra bontottam (1.2. program és 3.4. program) és a kezelőfelületek csoportokon belül kis mértékben térnek el egymástól. A rendszer több biztonsági funkciót is tartalmaz, például adott időben csak egy program lehet aktív. [4]

A PLC programban egy kevert programozási nyelvet (Ladder/FBD) választottam a programom megírására, mivel ebben a programozási környezetben a jelfeldolgozás könnyen kezelhető. A digitális vezérléseket és feltételeket létradiagramban, míg az analóg irányítást és visszacsatolást blokkdiagramban valósítottam meg. [5], [6], [7] 


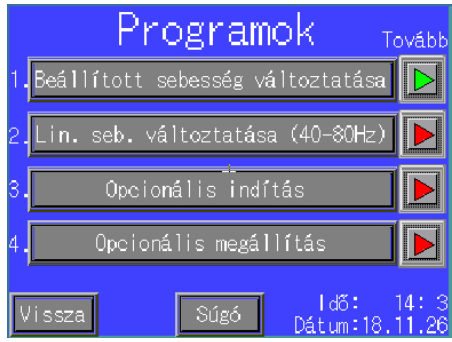

3. ábra. A rendszer 3. oldala (program kiválasztása)

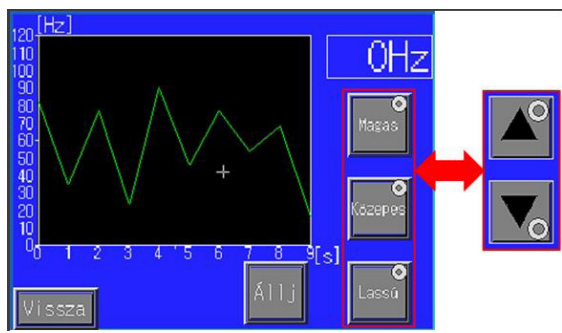

4. ábra. Első két program 3. felületei közötti eltérés

\subsection{Első programcsoport}

Az első két program kezelőfelülete 3-3 oldalból épül fel.

A HMI kezelőfelület első oldalán a programok irányításához szükséges információkat lehet megismerni. A második oldalon a motor forgásirányát lehet kiválasztani, valamint az indítás, állj és pillanat állj funkciók közül lehet választani. A harmadik oldalra csak a szállítószalag elindítása után lehet belépni, ahol a szállítószalag sebességét lehet beállítani a frekvencia változtatásával és emellett élő képet lehet kapni a frekvencia változásról grafikonon és számértékben is.

Az első példában három előre beállított frekvencia között lehet változtatni a motor fordulatszámát és így a szállítószalag sebességét. Ez a fajta felhasználás az élelmiszeriparban keverőtartály forgószerszámának sebességváltoztatására is alkalmas. Például különböző anyagokat kell öszszekeverni és a viszkozitás vagy technológiai folyamat miatt egyes anyagoknál alacsonyabb, míg más anyagoknál magasabb keverési sebesség alkalmazandó. Ezt a megoldást alkalmazzák még például gépi megmunkáló eszközöknél, vagy épületautomatizálásban is.

A második példában egy előre meghatározott skálán belül lehet a frekvenciát változtatni hertzenként. Ezt a felhasználást például ipari ventilátoroknál, szállítókocsiknál vagy az előző példában említett folyamatoknál használják, amikor elengedhetetlen az előre beállított értékektől eltérő fordulatszámok alkalmazása.

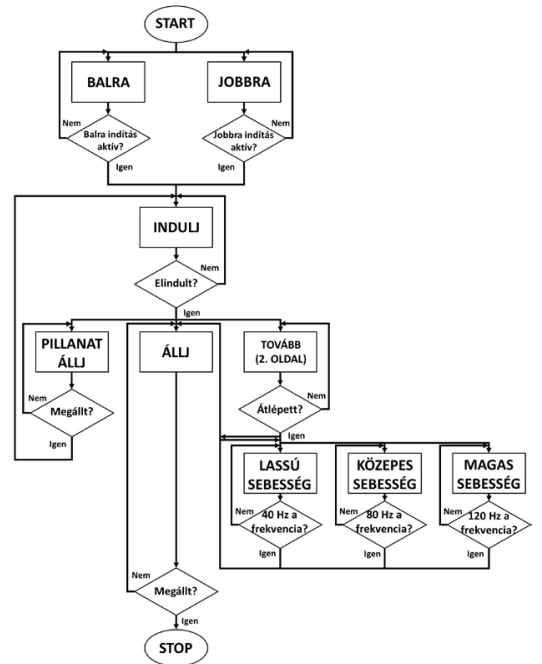

5. ábra. „Beállított sebesség változtatása” folyamatábrája

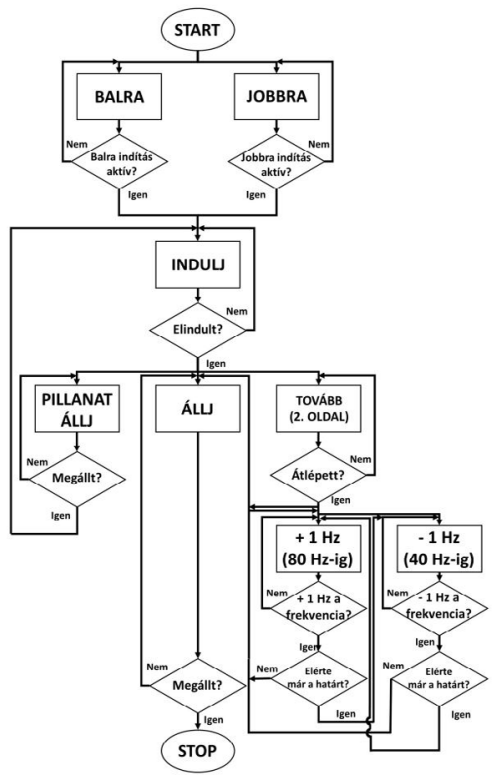

6. ábra.„Lineáris sebesség változtatása (40-80 Hz)” folyamatábrája

\subsection{Második programcsoport}

A 3. és 4. programok kezelőfelületei szintén 3-3 oldalból épülnek fel.

Az első oldalon a programok irányításához szükséges információkat lehet megismerni. A második oldalon el lehet indítani és meg lehet állítani a szállítószalagot, valamint aktiválni és deaktiválni lehet a lágy indítást/megállást. Lehetőségünk van mind két programban az indulási/megállási sebességek változtatására jelszó birtokában. 


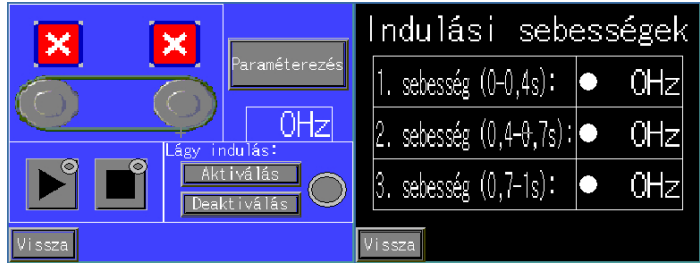

7.ábra., Opcionális indítás” 2. felülete

8.ábra. „Opcionális indítás” 3. felülete

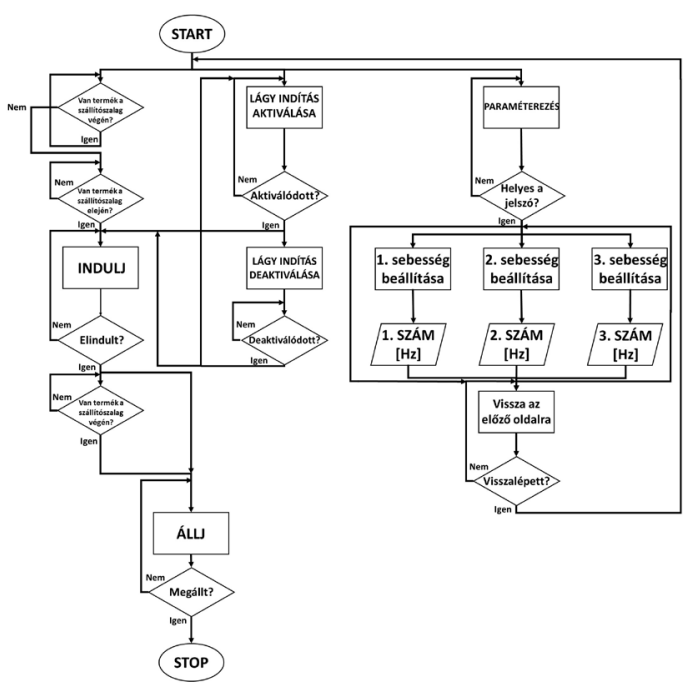

9. ábra. „Opcionális indítás” folyamatábrája

A harmadik programban a szállítószalag opcionális indítását mutatom be. Ezt a programot például szállítószalagok vagy szállítókocsik fokozatos indításánál alkalmazzák, hogy indításkor a szállítandó anyagok ne boruljanak fel hírtelen indulás hatására.

A negyedik programban a szállítószalag opcionális megállítását mutatjuk be. Ezt a programot az előző példához hasonlóan például szállítószalagoknál és szállítókocsiknál lehet felhasználni a fokozatos megállításra, így a szállítandó anyagok nem borulnak fel megálláskor. Emelőszerkezetek (pl.: lift) esetében pozícionálást lehet megvalósítani, így a mozgatott termék nem fut túl a kívánt véghelyzeten.

\subsection{Az 5. felhasználási elv}

Terveim között szerepelt, egy ötödik program megvalósítása, mellyel terhelés megváltoztatására a szállítószalag tartja a sebességét. Ezt a példát faiparban fürész korong meghajtásánál, amikor a feldolgozandó fa keménysége változik. Továbbá szivattyúknál hidraulikus tápegységeknél nyomás tartására szokták alkalmazni. Ennek a programnak a megvalósítására nem volt szükség, mivel az általam választott frekvenciaváltóban ez a funkció biztonsági elemként működik és jelen van.

\section{Következtetések}

Ipari eszközök segítségével egy olyan komplex mechatronikai rendszert hoztam létre, mellyel demonstrálhatók a frekvenciaváltós hajtás felhasználási elvei ipari körülmények között. Az operátor felületen élő képet kaphatunk a frekvencia változásáról. Biztonsági funkció céljából több esetben is jelszó birtokában lehet állítani a megadott paramétereket.

A megépített rendszerem kiválóan felhasználható oktatási célra egyetemeken, gyakorlati órákon és vállalatokon belüli továbbképzéseken is. A megépített modellemen keresztül be lehet mutatni egyszerre négy különböző megoldást frekvenciaváltós hajtás alkalmazására, azaz adott ipari folyamatokat, megoldásait lehet demonstrálni használatával.

\section{Modellem müködése:}

\section{https://youtu.be/oG2GZd39ds4}

\section{Szakirodalmi hivatkozások}

[1] Kuczogi E.: Villamos hajtások. Müszaki könyvkiadó, Budapest, 1976.

[2] Tóth J.: Automatika. TERC Kereskedelmi és Szolgáltató Kft, Budapest, 2013.

[3] Bartha I., Husi G., Liker I., Vitéz A., Tóth J.: Kapcsolási elrendezés és eljárás elektromos jármü váltakozó áramú hajtásának vezérlésére. P1200240. Magyarország, 2013.

[4] Sipos K., Tóth J.: Elektropneumatikus szelepek áramlási veszteségének mérése ipari eszközökkel. Műszaki és Menedzsment Tudományi Közlemények 2. kiadás, 2017. 68-72.

[5] Dombi K. B., Tóth J.: Meglévő automatizált épületek integrációja. In: A XXIII. Fiatal müszakiak tudományos ülésszak előadásai. Proceedings of the $23^{\text {rd }}$ international scientific conference of youngth engineers, Kolozsvár/Cluj, Románia, Műszaki Tudományos Közlemények 7. (2018) 67-70.

[6] L. Coutinho Alves Meiga, Tóth J.: Control and Position Memory of a TTR Robot. Annals of the University of Oradea Fascicle of Management and Technological Engineering 25. (2016) 115-118.

[7] Tóth X. E., Tóth J.: How to Control a Pneumatical and an Electrical Driven Linear. Annals of the University of Oradea Fascicle of Management and Technological Engineering. 24. (2015) 185-188. 